\title{
The Dialogue ONARISTOTLE CATEgories By PoRPHYRY AS A Platonic Dialogue
}

\author{
OKSANA YU. GONCHARKO AND DMITRY N. GONCHARKO \\ Saint-Petersburg Mining University \\ Russian Christian Academy for Humanities \\ goncharko_oksana@mail.ru \\ goncharko@list.ru
}

\begin{abstract}
The paper focuses on interactive dialogue-form strategies in the framework of the late antique Greek and early Byzantine logical traditions. The dialogue by Porphyry On Aristotle Categories is a perfect example of the Neoplatonic approach to build logic in a Plato style. The main protagonistresses of the dialogue are The Question and The Answer, who act as collocutors do in traditional Platonic dialogues. It is proposed to consider the dialogue in the context of three perspectives: in accordance with the tradition of the Platonic dialogue; in the light of Aristotle's education system; in its relation to the late antique and medieval Greek logical dialogue experiments.

KEYWORDS: history of logic, late antique logic, Platonic dialogue, Byzantine philosophy.

* The present study is a part of a larger project "The Byzantine Roots of the Russian Logical Tradition," Nr 18-78-10051, implemented with the financial support of the Russian Science Foundation (В статье представлены исследовательские результаты, полученные при выполнении проекта РНФ № 18-78-10051 «Византийский фактор в формировании русской логической традиции»).
\end{abstract}

Within the history of logic, especially in the framework of its ancient and medieval stage, the dialogue genre as a genre of presenting logical ideas was not very popular. Such a state of affairs has quite an understandable reason: the classical genre of research on logic themes was, as a rule, a monologic treatise, due to the necessity of logical knowledge, its universality and even its anti-dialectical nature. However, both the Antiquity and the Middle Ages give examples of interactive dialogue forms for presenting logical ideas. First and foremost, Plato used the dialogue as a method of defining concepts. Among Aristotle's non-preserved texts on logic, the German encyclopedia (Paully 1894) mentions a dialogue On Categories, the aim of which was to carry out preliminary training for further reading of

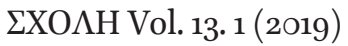

(c) O. \& D. Goncharko, 2019 www.nsu.ru/classics/schole DOI: 10.25205/1995-4328-2019-13-1-83-93 
84 Porphyry's On Aristotle Categories as a dialogue

the Categories. In addition to the well-known treatise Isagoge by Porphyry one can also find a commentaries on the Categories (Busse 1887), composed in the

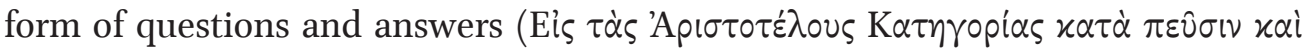
$\dot{\alpha} \pi \dot{x}$ p

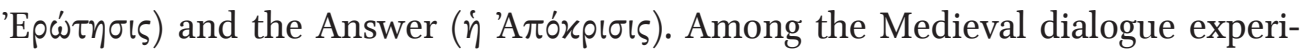

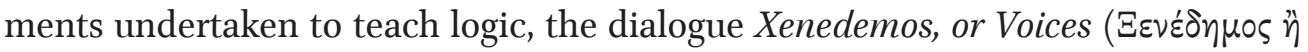
$\Phi \omega \nu \alpha i$ ) by Theodoros Prodromos (Spyridonova, Kurbanov, Goncharko 2017) deserves special attention as an interesting "dialectical" and ironical text dealing with the logical definitions of the five predicables of Porphyry. It could be argued that the five parts of this dialogue present five logical puzzles based on the text of the Isagoge, which could be regarded as a helpful tool for a better understanding and an active and creative studying of the Porphyrian introductory text. Finally, such a medieval logical dialogue-form genre as a dispute (disputatio) deserves special attention as a formal way of conducting a discussion in the scholastic system of logical education in Western Europe, created both for educational purposes and for the purposes of investigating the truth sentences in theology or other fields of Medieval knowledge. It is proposed in this paper to focus on the Platonic genre characteristics and the Platonic themes in the dialogue On Aristotle Categories presented by Porphyry to initiate the study of the categories as the beginning of any other logical studies.

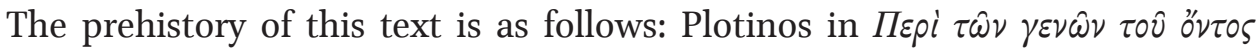
(Enn. 6.1-3) criticized the system of categories, systematically expounding a number of arguments against the Aristotelian text. Quite on the contrary, his pupil Porphyry wrote the Isagoge referring to the texts of Aristotle as included in Neoplatonic tradition (Strange 1987, 1) and while dedicating this work to one of his students, in fact, polemized with his teacher, answering his objections to Aristotle (Strange 1987, 2). The most of the late antique authors offered us this version of the prehistory of the dialogue (for example, Simplicios, Dexippos, etc.). However, Steven K. Strange criticizes this approach as the one which understates the role and significance of Porphyry within the history of logic and metaphysics, and also in the consideration of the fundamental issue of Neoplatonism, i.e. the question of the relationship between the philosophy of Plato and Aristotle. This approach by Simplicius and others presupposes a polemic between Porphyry and Plotinos, whereas their approaches to the Categories are not so opposite to each other as it seemed to the late antique authors, and moreover, one can even speak of continuity in this respect between Plotinos and Porphyry (Strange 1987, 2-3). Being a reflection of a real dialogue, On Aristotle Categories is also written in a dialogue form. This raises a question, whether this dialogue is a Platonic one in terms of its genre characteristics, as well as its content. 
As a first issue, the formal aspects of the text will be considered. At first glance, the dialogue does not resemble Plato's dialogues as they are. In the dialogue by Porphyry there are only two "actors" (or more precisely they are the "actresses" in

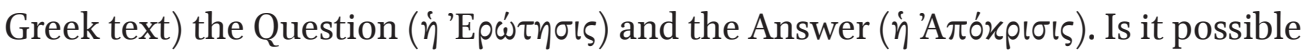
to affirm them as being the "collocutors" of the dialogue, and not the formal set of answers to the set of questions? On the one hand, the Question and the Answer address each other as addressee (the second person in grammatical sense) as true interlocutors do. On the other hand, the questions are not always asked on behalf of the Question. She (the Question) formulates not only questions, but also statements or even imperatives. For example, saying "Show us by example what you mean" (Porph. In Arist. Cat. 2 r 19). Sometimes it seems that Question even examines the Answer like teachers used to do, for example, asking the following questions: "What other argument can you give?" (In Arist. Cat. 34 v 22) or "Can you state this argument in a concise and syllogistic form?" (In Arist. Cat. $34 \mathrm{r}$ 15), etc. The same is also true concerning the Answer, i.e. she poses the questions as well as answers them. On the other hand, one can find some sort of continuity of the theoretical disposition presented by the Answer and that of by the Question, which allows us to declare them as characters that preserve self-identity throughout the entire text, rather than a set of independent questions and a set of independent answers. It could be illustrated by several cases that the Question resembles a Plotinos-like theoretician, who tries to defend the opinion that the treatise is devoted to the things and the genera of the things. For example, he raises some kind of provocative questions, which seem to be a consequence of the internal wish to find the contradictions within the position, which regards the Categories as dedicated to the words ( $\alpha i \varphi \omega \nu \alpha i)$ rather than the things and their genera ( $\tau \dot{\alpha} \gamma \varepsilon \dot{v} \eta)$ : "Why does he not discuss homonymy before discussing homonyms, given that 'homonymy' is a word, whereas homonyms are things, and you claim that he is primarily concerned in this treatise with words $(\pi \varepsilon p i \varphi \omega \nu \omega \hat{\omega})$, not with things $(\pi \varepsilon \rho i \tau \hat{i} \nu \pi \rho \alpha \gamma \mu \alpha \dot{\tau} \omega \nu)$ " (Porph. In Arist. Cat. 5 v 22-26). It really resembles the position of Plotinos, who claimed that the Categories are dedicated to the genera of being ( $\pi \varepsilon p i \tau \hat{\omega} \nu \gamma \varepsilon v \omega \hat{\omega} \nu \tau \hat{\omega} \nu$ oैv $\tau \hat{\omega} \nu$ ) as Porphyry put it (In Arist. Cat. $4 \mathrm{r} 33$ ). The Answer deals with this case like a modern non-classical semanticist, claiming that homonymy is a property of both the categories and the being itself: "I claim that Aristotle discusses homonyms first, because he holds that being ( $\tau$ ò ob) is a homonym and because predications are homonymously said to be the predications of that of which they are predicated" (In Arist. Cat. 5 v 19-21). For "until it is recognized that a word applies to a number of things that do not share the same account, there cannot be homonymy" (In Arist. Cat. 5 v 29-30). It is a very elegant opinion, which is very close to the Porphyrian position that without 
considering the things ( $\tau \dot{\alpha} \pi \rho \dot{\gamma} \gamma \mu \alpha \tau \alpha)$ it is impossible to talk about the properties of the words, which nevertheless is the real object of the treatise: "Because what produces homonymy in words is not the character of the expression itself ( $\delta$ $\chi \alpha \rho \alpha \chi \tau \dot{\eta} \rho \tau \hat{\jmath} \varsigma \lambda \dot{\varepsilon} \xi \varepsilon \omega \varsigma)$, but rather things are found to be different and in no way have anything in common yet acquire one and the same expression as their name" (In Arist. Cat. 5 v 26-28). We argue that this position could be regarded as exactly the Porphyrian one.

There is an opinion in the modern academic literature dedicated to this dialogue, which interprets the position of the Answer on the contrary as a Plotinian one, and that of the Question like a Porphyrian one, demonstrating it with the help of some cases where the position of the Answer coincides with the position of Plotinos. For example, one can find in the text of the dialogue such a passage by the Answer: "contraries would fall under the same genus and there is no common genus over body and the incorporeal" (In Arist. Cat. $32 \mathrm{v} 18-19$ ), which is close to the view which is insisted upon by Plotinos (cf. Enn. 6.1.2, 1-8 and 6.2.1, 16-28) that "there can be no common genus over corporeal and incorporeal substance" (Strange 1992, 104.). But we argue that the fact that Porphyry did make the Answer to express sometimes the position of Plotinos does not mean that this personage is Plotinos himself. On the one hand, Porphyry as a pupil of Plotinos could also be the adherent of a number of his statements. On the other hand, the Question is more similar to Plotinos, because the Question seems to examine the Answer throughout all the length of the dialogue, performing the function of provocative questions, which resemble the Socratic questions from Platonic dialogues; or the function of Plato himself, whom Aristotle answers frequently in his treatises, where Plato is not present to answer himself as a personage but his great pupil cannot ignore his position in every case or discussion; or at last the function of Plotinos concerning his pupil Porphyry. Thus, this dialogue could be regarded as a typical variation of polemics between the Great Teacher and his Great Pupil. And it does not matter which pair it is (Socrates/Plato or Plato/Aristotle or Plotinos/Porphyry), however, it is significant that the role of a teacher in all these cases is to question and to manage the discussion, yet not to dogmatize and demand.

To conclude, it should be mentioned that it is worth insisting on such a structural argument as the Answer should be regarded as Porphyry. It should be noted that the role of the Answer or the Pupil in Platonic-like dialogues is to reason and to discourse, while the role of the Question or the Teacher is a maeutic one to the extent of the very possibility of the examination to be a type of a maeutic procedure. The answers of the Answer are noteworthy and remarkable in the sense that the Pupil is allowed to change the approaches easily and investigate the issue 
from the different standpoints not being obliged to be stopped by one decision. It seems that it is exactly what Porphyry performed in the dialogue. He built a very "liberal" approach to the logical rules, which are in fact nothing else but human conventions on how to reason and to deduce something concerning categories. For example, when the Answer and the Question discuss what category the notions of "the great" and "the small" could be related to, the Answer shows it to be

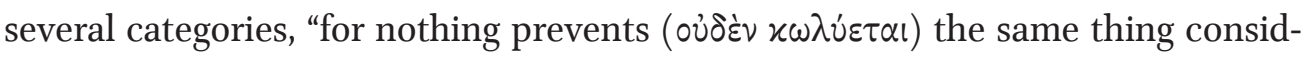
ered in different ways $\left(\kappa \alpha \tau^{\prime} \alpha^{\prime} \lambda \lambda_{0}\right.$ xai $\left.\alpha^{\prime} \lambda \lambda_{0}\right)$ from falling under several categories ( approaches are equal and could be accepted. And it resembles the emergence of the plurality of logics in the middle of the 2oth century. Though, for example, in the 12th century, Theodoros Prodromos, commenting on this passage of Porphyrian text, did not allow this plurality of approaches to co-exist together (Goncharko et al. 2018).

To show that the dialogue by Porphyry could be regarded as a Platonic one, it is necessary to consider as a second issue of our inquiry the presence in the text of the substantial Platonic content. Probably Porphyry being one of the Neoplatonic philosophers would like to assume that Aristotle admits to some extent the existence

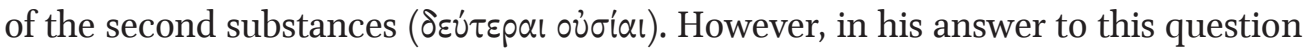
he rather identifies his position with the Peripatetic understanding of the Categories as a doctrine on concepts as linguistic phenomena (the predicates). Porphyry interprets the Categories primarily as a text on logic that can be read even by beginners without preliminary preparation, and without dealing with metaphysical issues. Therefore, the contradictions between Aristotle and Plato on the ontological status of the first and second substances are transferred by him from the level of ontology to the linguistic level. Thus, Porphyry managed to cope with the quite obvious anti-Platonism of the Categories (Strange 1992, 9). According to Porphyry, Aristotle did not consider the individual substance to be prior to the universal one (i.e. the Platonic idea or the form), but he considered it as a representative of its own species or genus to be prior to its predicates (i.e. the species and the genus as predicates $(\kappa \alpha \tau \eta \gamma o p o u ́ \mu \varepsilon v \alpha)$ ) (Strange 1992, 10). In other words, it is impossible according to Porphyry to consider the genera and the species as predicates without their relation to the set of individual entities, which are denoted by them (Strange 1992, p.10). It could be affirmed, that Porphyry distinguished between different types of universals being, on the one hand, the "abstract" ones ( $\propto \alpha \tau \gamma$ ү predicamenta) and, on the other hand, the "real" ones, i.e. Platonic ideas or forms (Lloyd 1981). In this respect, the word (घiठos) sounds ambiguous in the text of Porphyry, because Plato used it concerning the sense of the "form" and Aristotle the sense of the "species". In other words, Aristotle did not mean according to 
Porphyry that "a single particular substance taken by itself is prior to its universal, but that the whole class-extension of a universal predicate is prior to it" (Strange 1992, 10). The abstract universals (conceptual existences) are indeed posterior to sensible things, but they are not the same as the real universals (Platonic forms) in the light of "the primary purpose of language", which is to communicate about ordinary things and their individual properties (Lloyd 1981). The same approach one can find in the texts of Alexander of Aphrodisias, who also tried to accuse Aristotle of inconsistency. For example, in the Second Analytics there is a passage about the fact that universals are prior to things according to the order of nature (Anal. Post., 71b29-72a5). Neoplatonic philosophers commenting on this inconsistency used it for their own purposes (Strange 1992, 10). For example, Theodoros Prodromos due to this reason even tried to make logic an object for dialectical consideration. He built his commentaries on the Isagoge and the Categories in the genre of Platonic dialogue trying to show that the very primitive notions of logic itself are of "dialectical" nature. We try to show that Porphyry did the same in his dialogue commentary on the Categories.

First of all, this question-and-answer commentary by Porphyry is a some kind of propaedeutic work which could be read, as Porphyry himself showed it right within the text, regardless of one's philosophical position (whether it is a Platonic one, or an Aristotelian one). Porphyry exploited the inconsistency of Aristotelian position (which consists of two obviously incompatible statements on the ontological status of general notions, i.e. universals are prior according to the order of nature, but they are posterior according to the logical order) to show that the Categories could be regarded as a Plato-compatible approach to the reconstruction of how the logic should work.

Porphyrian dialogue commentary begins, as a Platonic dialogue usually does, with consideration of the semantics of the word, which it is dedicated to, i.e. the word "category". Porphyry shows that Aristotle as Plato himself had used the strategy of "violating ( $\xi \varepsilon v i \zeta \varepsilon v)$ the accepted usage" of the words (In Arist. Cat. $2 \mathrm{r}$ 11) and had intended not what Hellenes did using the word "category" (o $\pi \alpha \rho \dot{\alpha}$

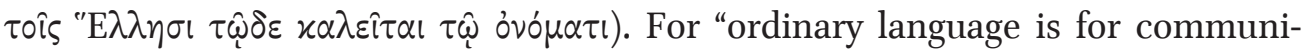
cating about ordinary things, and employs the expressions that are commonly used" (In Arist. Cat. 2r 12-14). Due to the fact that philosophers investigate un-

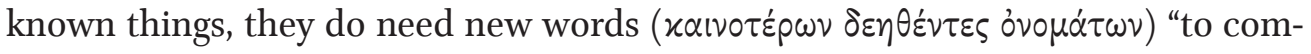
municate the things they have discovered" (In Arist. Cat. 2 r 15-16). That is why they have either to introduce new and unfamiliar expressions ( $\dot{\varepsilon} \pi \circ i \eta \sigma \alpha \nu \lambda \dot{\varepsilon} \xi \varepsilon ı \varsigma$

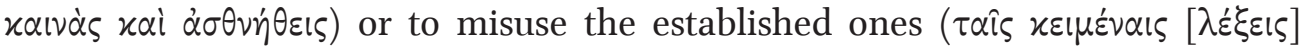

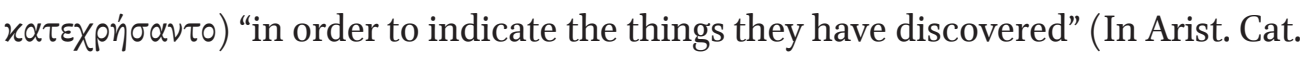


$2 \mathrm{r} 16-18)$. It should be noted that $\xi \varepsilon v i \zeta \varepsilon ı \nu$ (non-standard language usage) is not the same as $\varkappa \alpha \tau \alpha \chi p \hat{\eta} \sigma \theta \alpha \mathrm{l}$ (improper usage).

It should be mentioned that during the initial five paragraphs of the commentary, Porphyry used different forms of the three semi stem words with the close

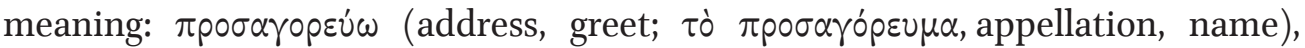

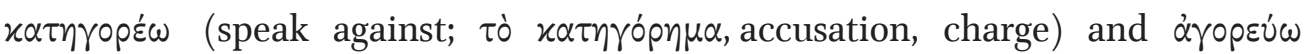
(speak in the assembly, say). In this situation, when we are obliged to invent new words or terms, what could be the reason to choose from the set of the synonyms or closely related stem words? Aristotle "chose to call 'predications' (

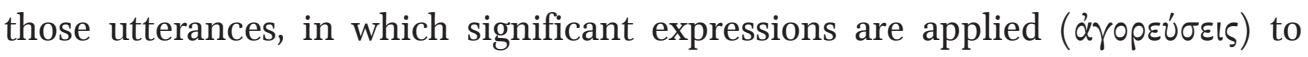
things" (In Arist. Cat. 2 v 10-11). Porphyry "played" with these stem words throughout all the initial part of the dialogue. For example, the extensive fragment (In Arist. Cat. 3 r $30-4$ r 10), being the passage on the distinction of two levels of language usage (the object-language usage ( $\tau \hat{\eta} \varsigma \pi \rho \dot{\omega} \tau \eta \varsigma \theta \varepsilon \dot{\varepsilon} \sigma \omega \varsigma$ ) and the

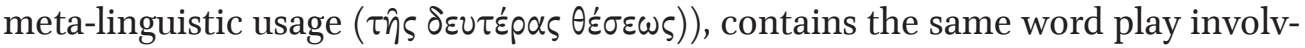

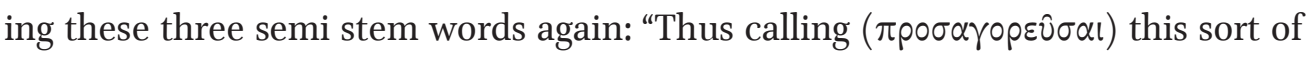
thing 'gold' and that material that shines so brightly 'the sun' belongs to the primary imposition of words ( $\tau \hat{\eta} \varsigma \pi \rho \omega \dot{\tau} \tau \varsigma$ $\theta \dot{\varepsilon} \sigma \varepsilon \omega \varsigma$ ), while saying that the expression

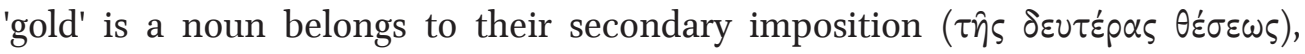
which signifies the qualitatively different types of expressions" (In Arist. Cat. $3 \mathrm{v}$ 15-19). Though, Porphyry affirmed (i.e. the Answer affirmed), that "the subject of the book is the primary imposition of expressions, which is used for communicating about things" (In Arist. Cat. 3 v 20-21), the main goal of the Porphyrian commentary is obviously meta-linguistic, i.e. the description of how the language works. On the one hand, there are ten genera of being ( $\tau \dot{\alpha}$ ö $v \tau \alpha)$, on the other hand, there are ten word types ( $\alpha i \varphi \omega \nu \alpha i)$, and also there are ten types of predica-

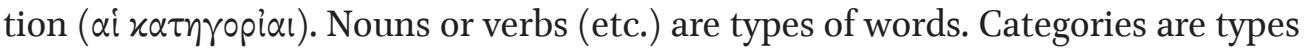
of predication, because their correspondence to things is significant in terms of ontology, and their correspondence to the genera of being ( $\dot{\eta} \dot{\varepsilon} \pi i \tau_{\alpha} \gamma^{\prime} \varepsilon_{\eta} \eta \dot{\alpha} \nu \alpha \varphi \circ \rho \dot{\alpha}$ ) is significant in terms of cognition. That is why the categories are not the simple words or names and are not things themselves, but significant expressions ( $\varphi \omega \nu \alpha$ i

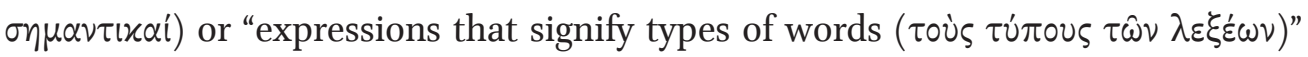

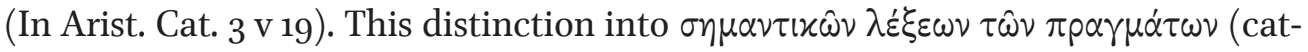
egories) and $\sigma \eta \mu \alpha \nu \tau i x \hat{\omega} \nu \lambda \varepsilon_{\varepsilon}^{\prime} \xi \omega \nu \nu \tau 0 \hat{v} \tau \dot{\tau} \pi 0 \nu \tau \hat{\omega} \nu \varphi \omega \nu \hat{\omega} \nu$ (noun, verb, etc.) is at the same time the distinction between the levels of using the language.

As the Answer suggests, the introductive part of the Categories on the synonyms, homonyms and paronyms has a logical status of axioms, which are necessary if someone tries to build the logic theory on how the words, things and their concepts are related to each other. We argue that in this respect, Porphyry works 
as a 2oth-century semanticist. He had set out the triangle of reference (semiotic triangle) very much like Gottlob Frege did: "each thing is indicated not only by its name, but also by the account that defines and conveys its essence” ( $\delta \varepsilon \lambda \circ v i \tau l ~ \gamma \alpha \dot{\rho}$

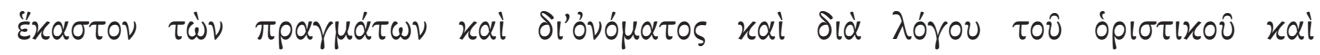

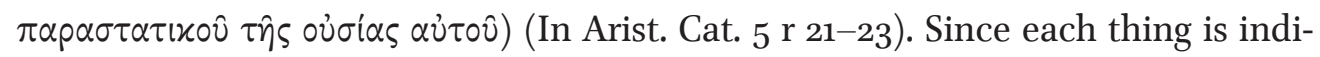
cated by its name and its defining account, "there are four sorts of relations that

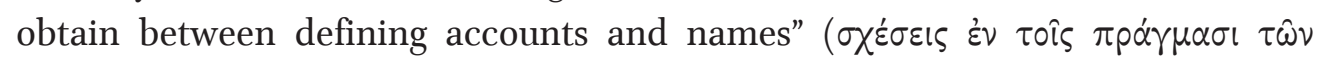

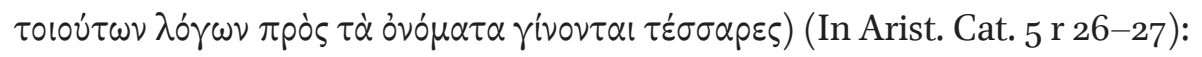

1. things either share both the same name and the same defining account (as synonyms do);

2. or the name but not the defining account (as homonyms);

3. or the account but not the name (polyonyms);

4. or neither the account nor the name (heteronyms).

Working out such a classification $(\sigma v \sigma \tau o x i \alpha)$, Aristotle according to Porphyry set out the axiomatic prolegomena to the further discussion of the categories: "Just as geometers begin by setting out definitions and axioms and postulates and divisions, which it is useful to have learned beforehand in order to grasp the theorems clearly, so Aristotle first takes up the matter of homonyms, synonyms, paronyms, and all the rest, as being most useful for the discussion of predications" (In Arist. Cat. $5^{\mathrm{r}} 5^{-15}$ ). It should be noted that the theory of categories by Aristotle is not a kind of axiomatic theory in the modern sense, neither it is within the text by Porphyry, but it is interesting that Porphyry raises such a parallel with geometry, maybe giving a hint of the direction, which should be developed. And this direction could be qualified as a nonclassical (i.e. non-Aristotelian) or a Platonic-like one.

Though Porphyry is a Platonic thinker, the object of his consideration is an Aristotelian one and it is very interesting to observe how he deals with Aristotelian logic in a Platonic-like manner. Some further examples could be discussed connected with the examination of "the great" and "the small" notions as a significant issue within the discussion on the categories, which could be useful to bring out the differences and similarities between Aristotle and Porphyry. The problem of classifying the concepts of "the great" and "the small" as related to one of the categories is a special issue discussed both within the Categories by Aristotle and On Aristotle Categories by Porphyry. The Aristotelian solution is an ambiguous one because Aristotle does not classify these concepts as related to any particular category, yet allows them to be referred to as different categories (that of quantity and of relation). Porphyry also touches upon the problem of classifying the concepts of "the great" and "the small", doing it in an elegant manner. Aristotle uses properties "to allow/not to allow opposites" or "to allow/not to allow more or less degree" (as well as other similar properties) to explore the distinctive features of 
different categories. That is why it is so important to find out which category the concepts of "the great" and "the small" belong to, since the very assignment of one or another category to these concepts can change our conclusions about the properties of each category in general. Talking about these concepts is important not only on a theoretical but also on a meta-theoretical level. For they are a kind of indicator of the differences between categories of quantity and relation and create real difficulty in classification of the categories. For these notions could be related simultaneously to both categories (quantity and relation) breaking up the classical (i.e. Aristotelian) rules of the division procedure. However, Porphyry does not apply these rules to the division into categories, but allows us to consider different concepts in terms of different categories. According to Porphyry, Aristotle considers the concepts of "the great" and "the small" only in a relative sense, that is, in terms of their attribution to the category of relation, and their attribution in the absolute sense to the category of quantity is not considered by Aristotle, although it is implicitly presented in the Categories. Porphyry even argues that after discussing the category of quantity comes the part dedicated to the category of relation precisely because the conversation about "the great" and "the small" as quantities needs to be continued by talking about them as related to the category of relation (In Arist. Cat. $35 \mathrm{r} 23-30$ ). That is why these concepts are so important within the theory of categories that even the sequence of their presentation by Aristotle is arranged by the decision of whether they are both the quantity and the relation or not. Porphyry to a greater extent than Aristotle examined the issue of the properties of categories and the grounds for attributing a particular category to something. Such a work on the meta-linguistic level determines to conclude that Porphyry resembles the non-classical logician of the 2oth century, who is obviously inspired by building some non-Aristotelian logic using some inconsistencies within Aristotelian texts. However, Porphyry as well as Theodoros Prodromos argue that Aristotle did not build a "dogmatic doctrine" in the Catego-

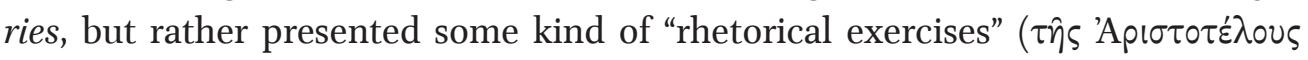

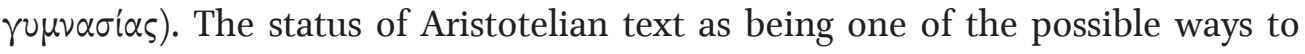
built logic or that of the "rhetorical exercises" (Shchukina, Egorenkova 2017) could really be assigned to him only by a Platonic thinker as Porphyry was. Or, for example, Theodoros Prodromos did the same in the short treatise On the Great and the Small (Tannery 1887, 117. 4). All this could become a substantial argument as to why the Answer should be regarded as Porphyry, and not Aristotle or Plotinos.

This Neoplatonic approach by Porphyry determined the accepted way to interpret the role of logic in the theory of cognition by the whole Greek medieval logical tradition. This approach by Neoplatonic philosophers from Porphyry and 
Theodoros Prodromos until our days erases the boundaries between the analytical (Aristotelian) and dialectical (Platonic) approach to thinking. It makes impossible the assertion that logical knowledge in its difference from the dialectical one is primarily consistent and free of contradictions. The situation of questioning the foundations of logical knowledge at a higher level of inquiry in the 19th and 2oth centuries gave birth to almost all non-classical logic frameworks (modal, temporal, relevant, para-consistent, etc.). It could be argued that the late antique and medieval Greek commentators on the Categories were fully aware of this point. At the same time, in most cases it happened precisely within the framework of the Neoplatonic tradition of commenting on Aristotle's Organon.

Plato's dialogue is a genre form, which Byzantine tradition perceived from the ancient literature. The dialogues in Platonic style were composed throughout the entire Byzantine millennium. However, the dialogue on logic only twice emerged in the history of logic, and both times they were the Platonic thinkers, who created such precedents (i.e. Porphyry in the $5^{\text {th }}$ century and Theodoros Prodromos in the 12th). Both times the "Platonic" critics of Aristotelian position were enclothed by the authors in the literary form of the Platonic dialogue because the interlocutors discussed Aristotelian definitions and distinctions and were led by Socratic dialectic method to the conclusion that the definitions are imperfect.

\section{REFERENCES}

Sources

Aristotelis analytica priora et posteriora, ed. W.D. Ross. Oxford: Clarendon Press, 1964. Plotinus, Plotini opera, eds. P. Henry, H.-R. Schwyzer. Leiden: Brill, 1951-1973.

Porphyrii isagoge et in Aristotelis categorias commentarium, ed. A. Busse (= Commentaria in Aristotelem Graeca 4.1). Berlin: Reimer, 1887.

Théodore Prodrome, Sur le grand et le petit, ed. P. Tannery (1887). Annuaire de l'Association pour l'encouragement des études grecques en France. T. 21. P. 104-119.

Strange, S. K., tr. Porphyry. On Aristotle Categories. London, 1992.

\section{Studies}

Charalampopoulos, N. G. (2005) "Enas platonikos dialogos tou $120 u$ aionos: Theodorou

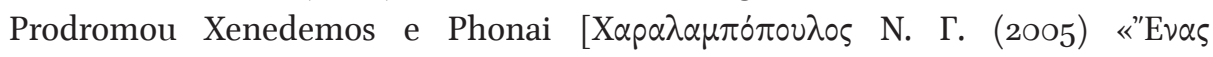

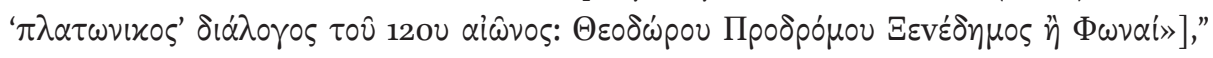
'Aprádvi (Ariadne) 11, 189-214.

Goncharko, O. Yu. (2013) "Dialogue and Pseudo-dialogue as a Genre in Greek Medieval Logic," Vestnik Russkoj Christianskoj Gumanitarnoj Akademii 14 (3), 224-230 [Гончарко, О.Ю. (2013) “Диалог и псевдо-диалог как форма изложения аристотелевской логики в Византии," Вестник Русской Христианской гуманитарной академии 14 (3), 224-23о]. 
Goncharko, O.Yu, Chernoglazov, D.A. (2016) "Platonic Dialogue "Xenedemos" by Theodoros Prodromos: Ancient Protagonists and their Byzantine Prototypes," $\Sigma X O \Lambda H$ (Schole) 10 (2), 571-583. [Гончарко, О.Ю., Черноглазов, Д.А. (2016) “Платоновский диалог «Ксенедем» Феодора Продрома: псевдоантичные герои и их византийские прототипы," $\Sigma X O \Lambda H$ (Schole) 10 (2), 571 - 583].

Goncharko, O.Yu., Goncharko, D.N. (2017) “A Byzantine Logician's 'Image' within the Second Iconoclastic Controversy. Nikephoros of Constantinople," Scrinium 13, 291-308.

Goncharko, O.Yu, Slinin, Ya.A., Chernoglazov, D.A. (2016) "Theodoros Prodromos Logical Works: "Xenedemos and Voices", Logicheskie issledovaniya 22 (2), 91-122 [Гончарко, О.Ю., Слинин Я.А., Черноглазов Д.А. (2016) “Логические идеи Феодора Продрома: «Ксенедем или гласы»,” Логические исследования 22 (2), 91-122].

Goncharko, O.Y., Slinin, Ya. A., Chernoglazov, D.A. (2018) "Theodoros Prodromos Logical Works: "On the Great and the small"," Logicheskie issledovaniya 24 (2), 11-35[Гончарко, О.Ю., Слинин, Я.А., Черноглазов, Д.А. (2018) “Логические идеи Феодора Продрома: «О великом и малом», Логические исследования 24 (2), 11-35].Lloyd, A.C. (1955-56) "Neoplatonic Logic and Aristotelian Logic," Phronesis 1, 58-72.

Lloyd, A.C. (1981) Form and Universal in Aristotle. Classical and Medieval Texts, Papers and Monographs. Liverpool.

Paully, A.F. (1894) Real-Encyclopadie der classichen Altertumswissenshaft. Stuttgart: J. B. Metzlerscher Verlag.

Shchukina, D., Egorenkova, N. (2017) "«Rhetoric practice» by I.S. Rizhsky (1796) at the Mining University: History and Contemporaneity," Zapiski gornogo instituta 225, 376-384. [Щукина, Д., Егоренкова, Н., 'Риторическая практика' И.С.Рижского (1796) в Горном университете: история и современность, Записки горного инcтumyma 225, 376-384.]

Spyridonova, L., Kurbanov, A., Goncharko, O.Yu. (2017) "The Dialogue Xenedemos, or Voices, by Theodore Prodromos. A Critical Edition, with English Translation," Scrinium 13, 227-275.

Strange, S. K. (1987) "Plotinus, Porphyry, and the Neoplatonic interpretation of the Categories," Aufstieg und Niedergagng der Römischen Welt 2.36.2, 955-74. 